\title{
Factors affecting sustainability of community food security projects in Kiambu County, Kenya
}

\author{
Mary Stella N Wabwoba* and Jacob W Wakhungu
}

\begin{abstract}
Background: Kenya is one of the countries in sub-Saharan Africa that is not able to feed its population sufficiently and it, therefore, relies on outside assistance. Many food security projects have been funded by both the Kenyan government and other development partners in an effort to mitigate against food insecurity. Unfortunately, as revealed by assessment reports, such projects leave little impact after the end of funding.

Context and purpose of the study: This study evaluated factors affecting the sustainability of community food security projects funded by various organizations between 2005 and 2009 in the Karai and Ndeiya divisions of Kiambu County, Kenya. This study was necessary because among the literature reviewed, no other study had been done on the sustainability of community food security projects. An evaluation research design was adopted and a purposive sampling method was used to select key informants from stakeholder organizations and project groups. Data were collected using face-to-face interviews with ten key informants (community-based organizations, faith-based organizations, financial institutions and the government of Kenya) and focus group discussions with twenty groups (ten women's groups, four men's groups and six mixed groups) that had benefitted from the funded projects. The data collected were analyzed using the chi-square test at the 95\% confidence interval level.

Results and main findings: The findings revealed that the sustainability of community food security projects is affected by group members' participation, rainfall patterns, leadership, management and funding levels.

Conclusions and recommendations: Based on the outcome of the study, we conclude that food security projects are not sustainable. The recommendation is that group members (the beneficiaries) must participate in project planning and implementation for purposes of ownership and sustainability. Farmers need to be empowered with knowledge on irrigation and off-season intensive farming of high-value crops. We are very optimistic that this recommendation will be useful for program planners, donors, policymakers, implementers and stakeholders in project design and for funding sustainable community food projects. A further study should be done on the role of stakeholders in project sustainability.
\end{abstract}

Keywords: Sustainability, Community food security projects, Kiambu County, Kenya

\section{Background}

Over the years, the government of Kenya has invested in community food security projects as a way of helping local people improve their own lives and livelihoods. A number of communities in Kenya have been given grants and technical support by both local and international donors, with the intention of helping them combat food insecurity and reduce poverty [1]. A study carried out in 2007 revealed that all the 15 development partners who

\footnotetext{
*Correspondence: wabstella@yahoo.com

Department of Disaster Management and Sustainable Development,

MasindeMuliro University of Science and Technology, Kakamega, Kenya
}

operated in Kiambu County targeted rural community food security projects [2]. Such donors included community-based organizations, faith-based organizations, financial institutions, the government of Kenya and other private organizations [3]. A total of 536 groups were funded between 2005 and 2009 by various organizations [4]. The report further revealed that some community projects were funded by as many as five donors during the same period.

Projects are intended to produce benefits that continue after some specified period of time. The goal of development assistance is to improve the quality of life and 
increase incomes. However, many projects, including those undertaken by international development organizations, fail to fulfill these objectives [5]. An impact assessment on community-funded projects showed that only 5 out of 36 groups funded in 2007 by NjaaMarufuku Kenya (NMK) were partially active, while the rest had become defunct and could not be traced after cessation of funding [6]. Despite the many funded food security projects in Kiambu County, there is persistent food insecurity among the rural communities [2]. The residents of Kiambu West (Kikuyuand Limuru) have high rates of malnutrition due to food insecurity [7] and yet Kiambu County has the largest number of community food security funded projects in Kenya [8]. The purpose of this research was to examine the factors that could be responsible for community projects not continuing to achieve their objectives and, therefore, forthe persistent food insecurity even among the funded groups.

\section{Methodology}

This study was conducted in Kiambu West (Kikuyu and Limuru) of Kiambu County, Kenya, which was purposively chosen because it has many community food security projects (Figure 1). Kiambu County has a total population of 834,378 of which 411,074 are males and 423,304 are females. The county covers an area of $1,207.4 \mathrm{~km}^{2}$, it has 235,417 households and it has a population density of 417.5 persons per $\mathrm{km}^{2}$ [9]. The county is in agro-ecological zone $2-4$ in the Central Kenyan highlands with an altitude ranging from $1,400 \mathrm{~m}$ to $1,800 \mathrm{~m}$ above sea level. It experiences bimodal rainfall between March and May and in October and November with annual rainfall above $1,500 \mathrm{~mm}$. The county is situated between latitude $0^{\circ} 75^{\prime}$ and $1^{\circ} 20^{\prime}$ south of the equator and longitudes $36^{\circ} 54^{\prime}$ and $36^{\circ} 85^{\prime}$ east.

Food security projects that operate in the county funded through government departments include:NMK [6], the Arid Lands Resource Management Project [10],

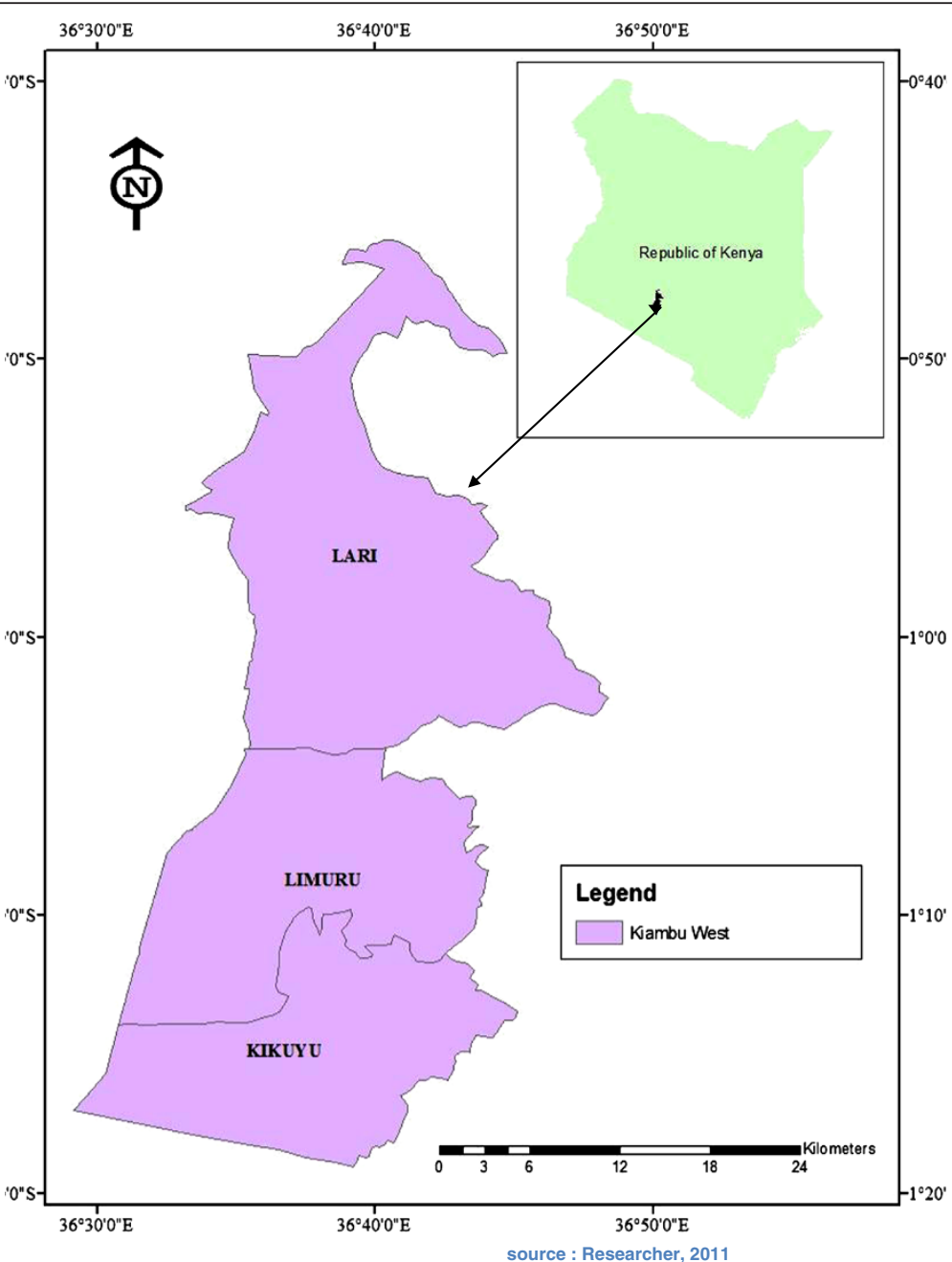

Figure 1 Kiambu west subcounties, Kenya Source: (Researcher, 2011). 
Table 1 Community groups from Karai and Ndeiya divisions, Kiambu County, Kenya

\begin{tabular}{|c|c|c|c|}
\hline Group type & Sampling method & $\begin{array}{l}\text { Sample } \\
\text { size }\end{array}$ & Names of groups \\
\hline Women's group & $\begin{array}{l}\text { Purposive and simple } \\
\text { random }\end{array}$ & 10 & $\begin{array}{l}\text { Thigio, Tiekumu, Nderu, NdiuniKarai, Mwireri, Nyathuna, Ruku, Bathoma, } \\
\text { Karii }\end{array}$ \\
\hline Men's group & $\begin{array}{l}\text { Purposive and simple } \\
\text { random }\end{array}$ & 4 & Ikaitano, Gatune, Nachu, Rusingiti \\
\hline $\begin{array}{l}\text { Self-helpgroup (mixed } \\
\text { gender) }\end{array}$ & $\begin{array}{l}\text { Purposive and simple } \\
\text { random }\end{array}$ & 6 & Renguti, Mwirimiri, jashoMukawa, Karisi, Makerecha \\
\hline Total & & 20 & \\
\hline
\end{tabular}

the Total War AgainstAids Project [11] and the Community Based Nutrition Program [12]. Most of these projects are concentrated in the Karai and Ndeiya divisions, which have a high incidence of malnutrition and food insecurity [13]. The study population comprised community groups, opinion leaders, non-governmental organizations, faith-based organizations and Kenyan governmentheads of departments that were involved in food security projects in Kiambu West (Karai and Ndeiya).

An evaluation research design was adopted and a purposive sampling method was employed to select key informants from the above population. Key informants were interviewed and observation checklists were used as proxy indicators of food security. Both secondary and primary data were collected and analyzed using a chisquare test at the $95 \%$ confidence level. Twenty different types of focus group discussions were conducted in theKarai and Ndeiya divisions as shown in Table 1. The variables analyzed were: group activities, functions of group members and the factors and challenges hindering goal achievement by groups.

\section{Results and discussions}

\section{Group activities implemented by members}

The study sought to discover the group activities implemented by members, which could be contributing to success or failure of projects. The focus group discussions revealed that $60 \%$ of the people had crops as their main activity, 30\% practiced off-farm activities and 10\% kept livestock (Table 2). The calculated chi-square of 135.45 at two degrees of freedom showed a highly significant $(P<0.01)$ variation among group activities. The researcher also observed most of the farms were occupied by crops (Figure 2). These findings are in agreement with the food

Table 2 Main activity of members of groups in Kiambu County, Kenya

\begin{tabular}{lll}
\hline Activity & Frequency & $\%$ \\
\hline Crop farming & 212 & 60 \\
Livestock farming & 35 & 10 \\
Off-farm activity & 105 & 30 \\
Total & 352 & 100 \\
\hline
\end{tabular}

security profile report for Kiambu County [14], which showed that $70 \%$ of the population is engaged in crop cultivation. Most farms (90\%) are smallholdings although a few larger holdings exist in the county [15]. This was confirmed by $93 \%$ of the key informants, who said they supported farming activity. Further group discussions revealed that off-farm activities, like public transport and construction of business premises, had taken up most of the land previously used for farming. It is unlikely that the money earned is used to purchase food, hence household food security is not guaranteed.

\section{Functions of group members in sustaining group projects} Focus group discussions were held to evaluate the functions of group members and the variables were: resource contribution, labor provision and attending meetings. The majority of the group members contributed resources (62\%) towards running the project's activities. Other members (40\%) attended meetings during which they are also trained by extension providers on various aspects of agriculture (Figure 3). The calculated chisquare of 147.01 at two degrees of freedom showed a highly significant $(P<0.01)$ variation among the members' function in sustaining group projects. Everyone in the community, regardless of gender or socio-economic status, is encouraged to provide opinions, make decisions and contribute resources towards the implementation of a Community Action Plan [16]. Oniang'o [17] emphasized that communities are extremely important

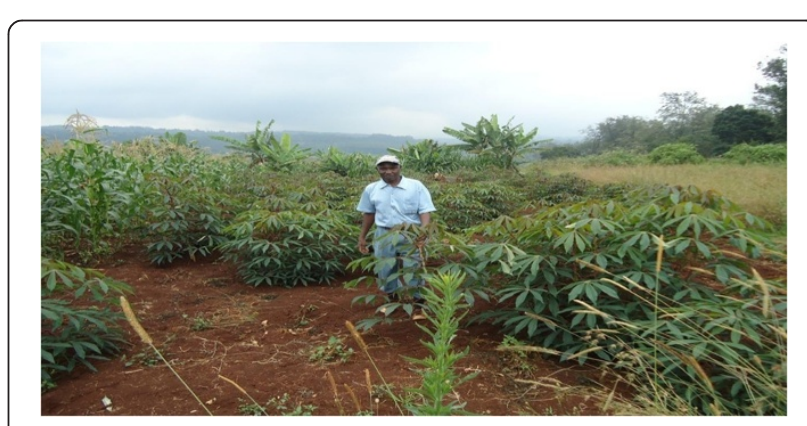

Figure 2 Mixed crop farm in Ndeiya, Limuru. 


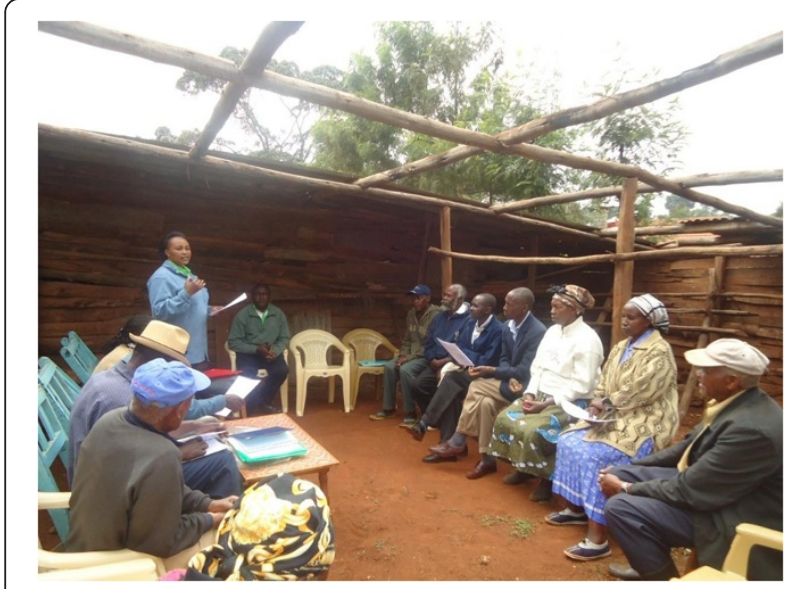

Figure 3 Focused Group discussion for Makerecha group in karai, Kikuyu.

in determining the sustainability of projects, since if they contribute resources there is an element of ownership.

Factors affecting sustainability of food security projects in Kiambu County

The respondents were asked to rank how the listed factors had affected their group using ratings such as no effect, low effect, high effect, higher or highest effect in achieving their group's objectives, and, hence, project sustainability. The ranking was determined by the percentage of the respondents voting for the factor that has the highest effect in hindering the group's objective. The examined variables are listed in Table 3.

The chi-square tests for group members' participation, land tenure and gender, and rainfall showed highly significant $(P<0.05)$ variation while level of funding, politics and management and leadership were significant $(P<0.0)$. The results imply that these factors contribute towards the food security of households and, therefore, will affect the sustainability of community food security projects. However, lack of knowledge, skills and communication

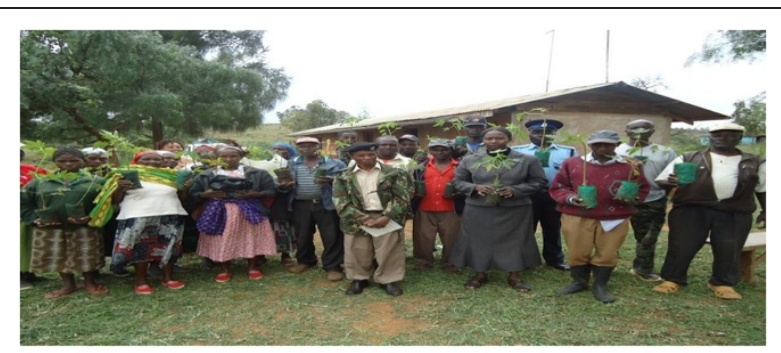

Figure 4 Renguti self help group with pawpaw project in Kikuyu, Kiambu.

networks were statistically not significant $(P>0.05)$. This means that these factors do not directly contribute towards food security and are therefore not major factors in community project sustainability because the majority of the groups are empowered with projects (Figure 4). Household interviews also revealed that middle-age people were actively involved in food security and therefore community food security projects should target this age group to ensure sustainability. This results show that food security is affected by the size of the farm owned by households and hence households with more land under food crop are more food secure. The presence of food is an indicator of project sustainability [18].

\section{Conclusions and recommendations}

Based on the findings from the study, the most significant factors affecting the sustainability of community food security projects in Kiambu County are: group members' participation, rainfall patterns, land tenure and gender, level of funds allocated to the project and the individual activities undertaken by members.

The study recommends that for Kenyan communities to enjoy food security through community projects, the following measures should be adopted: involve group members in project design, implementation, resource contribution, monitoring and evaluation, to ensure ownership and hence sustainability.

Table 3 Factors affecting the sustainability of food security projects in Kiambu County, Kenya

\begin{tabular}{|c|c|c|c|c|c|c|}
\hline \multirow[t]{2}{*}{ Number } & \multirow[t]{2}{*}{ Factors/challenges } & \multicolumn{5}{|l|}{ Level of effect } \\
\hline & & Highest effect \% & Higher effect \% & High effect \% & Low effect \% & No effect $\%$ \\
\hline 1. & Level of funding & 33 & 33 & 32 & 1 & 0.3 \\
\hline 2. & Lack of knowledge and skills & 34 & 30 & 3 & 33 & 0.6 \\
\hline 3. & Communication networks & 2.0 & 65 & 33 & 0.3 & 0 \\
\hline 4. & Land tenure and gender & 40 & 0 & 34 & 33 & 30 \\
\hline 5. & Rainfall & 63 & 3.4 & 33 & 0 & 0.6 \\
\hline 6. & Politics & 34 & 32 & 33 & 2 & 0.3 \\
\hline 7. & Collaborators and stakeholders & 33 & 32 & 2 & 33 & 0.3 \\
\hline 8. & Management and leadership & 0.3 & 33 & 33 & 32 & 1 \\
\hline 9. & Group members' participation & 66 & 31 & 1 & 2 & 1 \\
\hline
\end{tabular}




\section{Competing interests}

The authors declare that they have no competing interests.

\section{Authors' contributions}

JW conceived the study and participated in its design and coordination, helped to draft the manuscript and critically revised the text for important intellectual content. SO participated in the sequence alignment. Both authors read and approved the final manuscript.

\section{Acknowledgement}

We thank the Ministry of Agriculture staff in Kikuyu and Limuru, especially the District Agricultural Officer, Lucy Waweru, for allowing use of the office computers and printers, andthe divisional staff, H Muchui and J Njoroge, for assisting in collecting data in the Karai and Ndeiya divisions, respectively. Special thanks to our supervisors, Professor Jacob W Wakhungu and Dr Stanley Omuterema, who greatly sacrificed their time in providing guidance while developing this paper. Finally, thanks to Martin Kasina for analyzing the data.

Received: 6 January 2013 Accepted: 15 May 2013

Published: 24 June 2013

\section{References}

1. United Nations Development Programme: Kenya Briefing Report on Food Situation. Nairobi: Government printers; 2010.

2. International Federation of Red Cross and Red Crescent Societies: World Disasters Report 2009; Focus on Early Warning Early Action. Geneva: Red Cross publishers; 2009:23.

3. IFPRI: Reaching sustainable food security for all by 2020. Getting the priorities and responsibilities right. Washington, D.C: IFPRI Projects; 2002:36-38.

4. DDO (2009): District Development Office: Annual Report. Kiambu District. Nairobi: Government printers Un published, government report; 2009:17.

5. Hodgkin: Sustainability in Water Supply and Sanitation, Draft wash Report February. London press; 1994:15.

6. Ministry of Agriculture: Food Security Kenya Briefing, Update September 2010 Nairobi: Government Printers; 2010:3.

7. UNICEF: Determinants of Malnutrition in Children: A Conceptual Framework. Nairobi: Government printers; 2009.

8. World Bank, Independent Evaluation Group: Hazards of Nature, Risks to Development: An IEG Evaluation of World Bank Assistance for Natural Disasters. Washington, DC: World Bank; 2006.

9. KNBS: Kenya National Census Report, 2009. Nairobi: Government Printers; 2010:319-325.

10. Ministry of State for Special Programmes: Implementation Report Summary 2003-2010. Nairobi government printers; 2010:12.

11. Ministry of Health: Kiambu District Annual Report 2010, Unpublished Government report. Nairobi: Government Printers; 2010:25.

12. Ministry of Culture and Social Services: Project Progress Report 2007, Unpublished Government report. Nairobi: Government Printers; 2007.

13. Ministry of Agriculture, District Agriculture Office: 2011 Annual Report. Kiambu district, Unpublished Government report. Nairobi: Government Printers; 2011:12.

14. Central Bureau of Statistics: Kenya Demographic and Health Survey. Nairobi: Government Printers; 2008:15-17.

15. Ministry of Agriculture, District Agriculture Office: Food Production Based on Cereals Production in the District for 2009. Kiambu district: Unpublished Government report; 2009:14.

16. Mathu: Towards a praxis model of social work: a reflexive account of practical intervention. Nairobi University; 2005. Unpublished PhD thesis.

17. Oniang'o R: Interventions to Address Household Food security in Kenya, ACC/ SCN Symposium report. Accra: Ghana in February 1999; 1999:6.

18. Wabwoba: Factors affecting sustainability of food security projects in Kiambu, Kenya, Masters thesis 2012, MMUST. Kakamega: Lambert Academic publishers; 2012.

doi:10.1186/2048-7010-2-9

Cite this article as: Wabwoba and Wakhungu: Factors affecting sustainability of community food security projects in Kiambu County, Kenya. Agriculture \& Food Security 2013 2:9.

\section{Submit your next manuscript to BioMed Central and take full advantage of:}

- Convenient online submission

- Thorough peer review

- No space constraints or color figure charges

- Immediate publication on acceptance

- Inclusion in PubMed, CAS, Scopus and Google Scholar

- Research which is freely available for redistribution

Submit your manuscript at www.biomedcentral.com/submit 